\title{
Sperm quality of the Amazon catfish Leiarius marmoratus (Gill, 1870) after cold storage
}

\author{
Galo, JM. ${ }^{a *}$, Streit-Jr., DP. ${ }^{b}$, Povh, JA. ${ }^{c}$, Fornari, DC. ${ }^{d}$, Resende, EK. ${ }^{e}$, \\ Oliveira, D. ${ }^{b}$ and Ribeiro, $R P^{d}$ \\ anstituto Federal de Educação, Ciências e Tecnologia de Rondônia - IFRO, Câmpus Ariquemes, Rodovia RO-257, \\ Km 13, CEP 76870-970, Ariquemes, RO, Brazil \\ bDepartamento de Zootecnia, Universidade Federal do Rio Grande do Sul - UFRGS, Av. Bento Gonçalves, \\ 7712, CEP 91540-000, Porto Alegre, RS, Brazil \\ 'Faculdade de Medicina Veterinária e Zootecnia, Universidade Federal do Mato Grosso do Sul - UFMS, \\ Av. Senador Filinto Muller, 2443, Vila Ipiranga, CEP 79074-460, Campo Grande, MS, Brazil \\ ${ }^{d}$ Departamento de Zootecnia, Universidade Estadual de Maringá - UEM, Av. Colombo, 5790, \\ Bairro Zona 07, CEP 87030-121, Maringá, PR, Brazil \\ ${ }^{\circ}$ Embrapa Pantanal, Corumbá, MS, Brazil \\ *e-mail: juliana.galo@ifro.edu.br
}

Received: January 31, 2013 - Accepted: June 13, 2013

(With 4 figures)

\begin{abstract}
This study aimed at assessing the sperm quality of the Amazon catfish, Leiarius marmoratus, after refrigeration without extenders. After capturing the animals and stripping of semen, the following parameters were analyzed: progressive motility, motility quality score, duration of motility and sperm morphology. An aliquot of fresh semen from each male was kept at room temperature $\left(28 \pm 2^{\circ} \mathrm{C}\right)$ as a control, for further comparison with cooled semen. The semen from each animal was stored in extenders-free individual syringes. The syringes were kept in ice within polystyrene boxes at $13 \pm 2{ }^{\circ} \mathrm{C}$. For both fresh and cooled semen, seminal parameters were evaluated every one-hour interval, reaching seven hours of analysis. Fresh semen showed a significant decrease in motility, motility quality score and duration of motility remaining viable only for three hours. Progressive motility of the cooled semen displayed a negative linear pattern $(\mathrm{P}<0.05)$. The duration of motility increased $(\mathrm{P}<0.05)$, reaching its peak after three hours of storage. The motility quality score showed a quadratic pattern. No statistical differences were observed when sperm morphology was assessed $(\mathrm{P}>0.05)$, even though the mean values of total abnormalities have increased over the storage time. Further studies focusing on the application of this technique should be performed, including the addition of extenders and cryoprotectants for preservation of the sperm over longer periods.
\end{abstract}

Keywords: progressive motility, duration of motility, cooling, motility quality score.

\section{Qualidade espermática do Jundiá Amazônico Leiarius marmoratus (Gill, 1870) após o resfriamento}

\section{Resumo}

O objetivo deste experimento foi avaliar a qualidade espermática do Jundiá da Amazônia, Leiarius marmoratus, após resfriamento sem diluidores. Após a captura dos animais e coleta do sêmen, os seguintes parâmetros foram analizados: motilidade progressiva, vigor espermático, duração da motilidade e morfologia espermática. Uma alíquota de sêmen fresco de cada animal foi utilizada como controle, permanecendo em temperatura ambiente $\left(28 \pm 2^{\circ} \mathrm{C}\right)$ até o momento das análises. O sêmen de cada animal foi armazenado em seringas individuais, sem a presença de diluidores. As seringas foram mantidas em gelo dentro de caixas de poliestireno a uma temperatura media de $13 \pm 2{ }^{\circ} \mathrm{C}$. Os parâmetros seminais foram avaliados a cada hora, totalizando sete horas de análises. O sêmen fresco (controle) apresentou uma queda significativa na motilidade progressiva, vigor espermático e duração da motilidade, permanecendo viável apenas por três horas. As taxas de motilidade progressiva do sêmen resfriado apresentaram um comportamento linear negativo $(\mathrm{P}<0.05)$. Assim como a duração da motilidade aumentou $(\mathrm{P}<0.05)$, alcançando seu pico após três horas de resfriamento. $\mathrm{O}$ vigor espermático do sêmen resfriado apresentou um comportamento quadrático. Não foi observada diferença estatística na morfologia espermática do sêmen resfriado $(\mathrm{P}<0.05)$, embora o número total de anormalidades tende a aumentar com o decorrer do tempo. Estudos adicionais focados na aplicação desta técnica devem ser realizados, incluindo a avaliação de diluidores e crioprotetores para a preservação do sêmen por maiores períodos.

Palavras-chave: motilidade progressiva, duração da motilidade, resfriamento, vigor espermático. 


\section{Introduction}

Semen conservation by cooling can be efficiently applied to reproductive management of fish once it has lower cost compared to freezing techniques (He and Woods 3rd., 2003). According to Marques and Godinho (2004) refrigeration is a simple and alternative technique that allows short-term utilization of fish sperm, thereby optimizing the fertilization of eggs and assuring a higher productivity in the breeding process. An additional advantage is the easy transportation in proper recipients such as plastic bags (Stoss and Refstie, 1983) and plastic tubes (Chereguini et al., 1997; Wayman et al., 1998), not requiring use of liquid nitrogen containers.

Sperm quality is a key feature for a successful breeding process, especially in cases where spermatozoa have suffered physical changes by cooling. Studies on fish semen have shown some individual variations in parameters like sperm motility and fertilizing ability. Moreover, the spermatic indexes may vary among males or in the same individual (Rana 1995). Development of a cryoprotectant solution for fish semen depends on the assessment of toxic effects and its influence over the spermatic integrity and function (Ohta and Izawa, 1996).

Techniques for semen preservation under low temperatures have been used for several fish species in order to solve problems of asynchronies between males and females in captivity as well as to improve broodstock reproductive performance under farming conditions (Carneiro et al., 2006). Over the last years, studies on semen conservation of some native Brazilian fish species, such as Brycon orbignyanus (Maria et al., 2006), Rhamdia quelen (Carneiro et al., 2006) and Piaractus mesopotamicus (Streit Junior et al., 2007) have shown to be very useful due to their both economic and environmental importance.

The family Pimelodidae includes species, which display great potential for fish farming. However, some Pimelodid species exhibit high rates of cannibalism during early stages and are carnivorous, thus hampering their effective production in captivity. The utilization of hybrids between high market value carnivorous species such as Pseudoplatystoma fasciatum and Pseudoplatystoma corruscans with omnivorous species may reduce this issues (Mateo et al., 2008). In this context, Leiarius marmoratus has gained attention from Brazilian fish farmers to the commercial production of hybrids with $P$. corruscans. It should be highlighted that cryopreservation techniques have been decisive for commercial production of these hybrids once there is no reproductive synchrony between both selected species.

This study aimed at evaluating the sperm quality of the Amazon Catfish L. marmoratus after cooling storage without addition of extenders agents.

\section{Material and Methods}

The study was carried out in a fish farm located in Rondônia State, Northern Brazil, during the 2011 reproductive season of Brazilian migratory fish. The experiments were performed by staff of PEIXEGEN and Aquam research groups.

Six males of $L$. marmoratus were sampled at gonadal maturation stage, identified by a soft abdomen and releasing of milt when the abdomen was gently squeezed. Breeders were kept in tanks inside the laboratory, being weighed and identified with transponders (ID 100-A) of $11.5 \mathrm{~mm}$ in length and $2.2 \mathrm{~mm}$ in diameter with an operational frequency of $128 \mathrm{kHz}$. The transponders were subcutaneously implanted into the dorsal region of the fish.

To induce spermiation, a single dose of carp pituitary crude extract at $2.5 \mathrm{mg} / \mathrm{kg}$ of body weight was injected. The semen was stripped 180 degree-hours (accumulated thermal unit) after injection. Males were individually wrapped with wet towels and the urogenital papilla was cleaned and dried with paper towel before collecting the sperm. The semen was collected into $1 \mathrm{~mL}$ syringes (Billard et al., 1995). Seminal evaluation was performed soon after sampling, and the following parameters were assessed: progressive motility (\%), motility quality score ( 0 to 5 points), duration of motility (minutes) and sperm morphology (\%). Seminal analysis was performed following the recommendations of Galo et al. (2011).

After collection, the sperm of each animal was loaded into extenders-free individual syringes. An aliquot of fresh semen from each male was kept at room temperature $\left(28 \pm 2^{\circ} \mathrm{C}\right)$ as a control, for further comparison with cooled semen. Following the cooling procedures, the syringes were directly stored in dark polystyrene boxes filled with ice, keeping the temperature at $13 \pm 2^{\circ} \mathrm{C}$. For both fresh and cooled semen, seminal parameters were evaluated every one-hour interval, reaching seven hours of analysis. One way analysis of variance (ANOVA) followed by Tukey's post-hoc test was used for statistical analysis $(\mathrm{P}<0.05)$.

\section{Results}

Fresh semen (room temperature control) showed a significant decrease in motility, motility quality score and motility period (Figure 1). Only samples from two animals showed some motility and motility quality score after three hours of analysis.

There was a wide variation in the duration of motility among the males, in which samples from two males presented a higher resistance to cooling, once a motility rate of $40 \%$ was maintained for seven hours after stripping. On the other hand, spermatozoa from a third specimen lost their progressive motility after five hours following collection (Figure 2). The mean progressive motility of the cooled semen decreased gradually over time (Figure 3A).

The duration of motility, which displayed a negative linear pattern $(\mathrm{P}<0.05)$, was more pronounced as the storage time increased (Figure 3B). As the spermatozoa's movement ability decreased, the vigor also showed the same pattern.

The motility quality score showed a quadratic pattern through the time (Figure 3C). However, after seven hours $(\mathrm{T}=7)$ a vigor of 2.4 points was recorded, with no statistical differences between evaluations $(\mathrm{P}>0.05)$. 

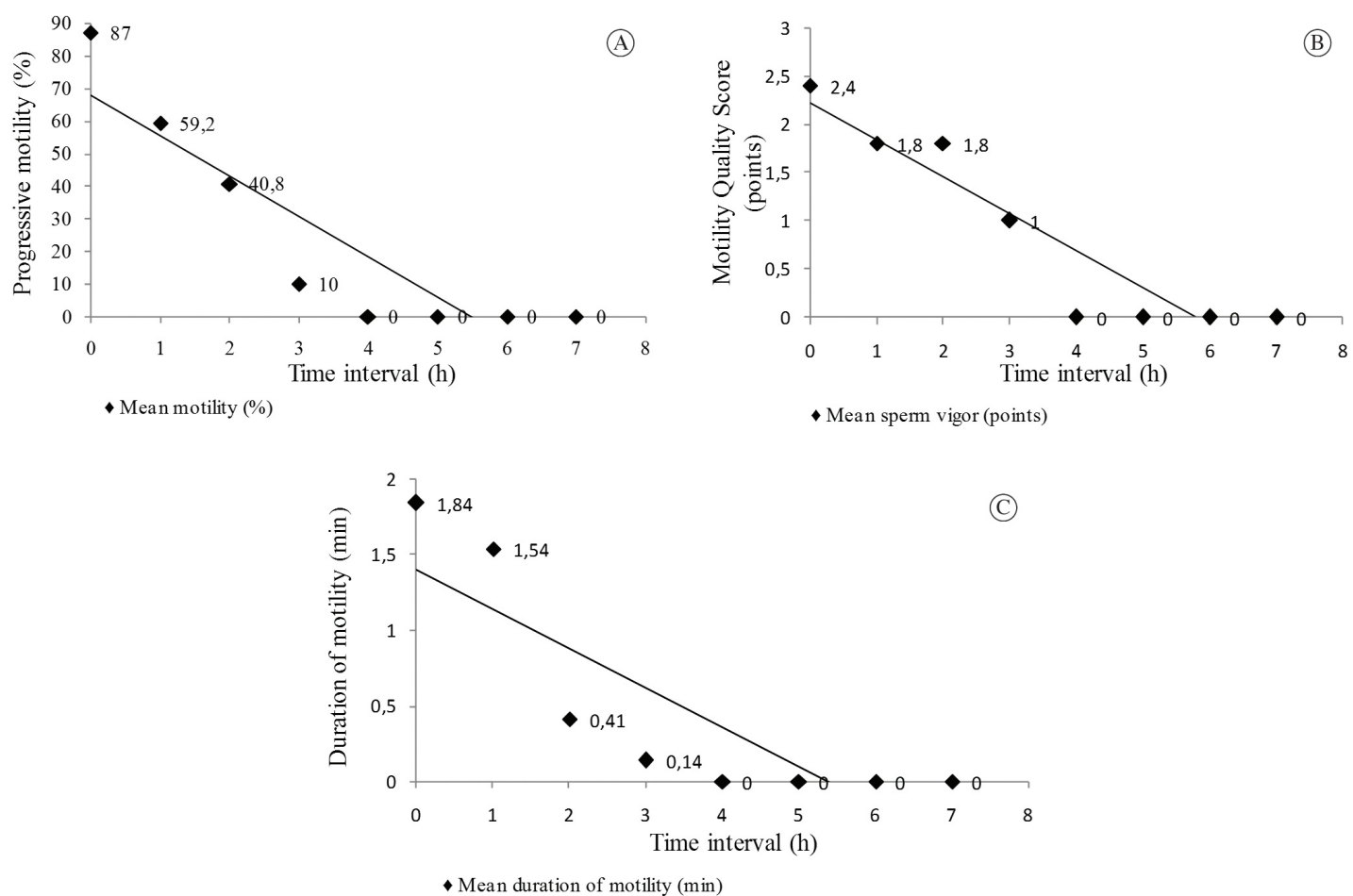

Figure 1. Spermatic parameters of Leiarius marmoratus fresh semen over the time. A - Progressive motility (\%), B - Motility quality score (points); C - Duration of motility (min).

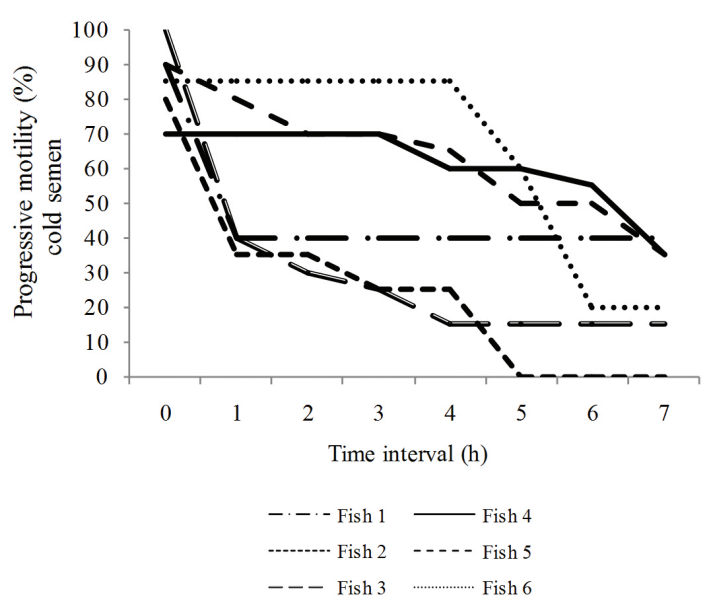

Figure 2. Progressive motility of spermatozoa (\%) from Leiarius marmoratus males according to time.

No statistical differences were observed when sperm morphology was assessed $(\mathrm{P}>0.05)$, even though the mean values of total abnormalities have increased over storage time (Figures 3D, 4).

\section{Discussion}

Differences in the spermatic indexes between males, races or within the same individual as observed in the present study are reported by Rana (1995) as one of main issues hampering the management of semen conservation. Babiak et al. (2006) working with Hippoglossus hippoglossus, and Sahinoz et al. (2007) studying Mastacembelus mastacembelus reported that the semen quality might vary according to each phase within the reproductive season.

Another hypothesis to explain the amplitude of seminal values is related to difficulties in handling spermiation. In fact, the semen stripping from L. marmoratus is an arduous one, requiring different strategies when compared to those traditionally employed to migratory fish species. Therefore, contamination by water, feces or urine might be common during stripping procedures and eventually leading to early sperm activation.

Some authors have reported several aspects that might affect the motility of in vitro stored spermatozoa, such as maturation age of animal, storage procedure (Ohta and Izawa, 1996), temperature, $\mathrm{CO}_{2}$ exposure (Bencic et al., 2000), $\mathrm{pH}$, oxygen concentration and urine contamination (Billard et al. 1997; Valdebenito et al. 2009).

An increase in the motility period was in some way expected. However, Billard and Cosson (1986) reported that the lifetime of fish spermatozoa is highly dependent on temperature and the $\mathrm{pH}$ of the extender medium. At low temperatures spermatozoa are less active than at higher ones, but their lifetime is frequently increased (Alavi and Cosson, 2006). It could be observed in the present study, when comparing the motility period of the fresh semen to that recorded for the cooled semen. 


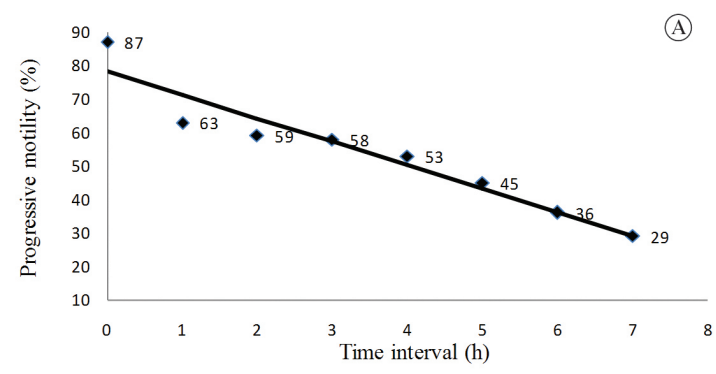

- Mean motility (\%)

—Estimated motility $(\%)=78.25-7.00 \times$ cooling hours

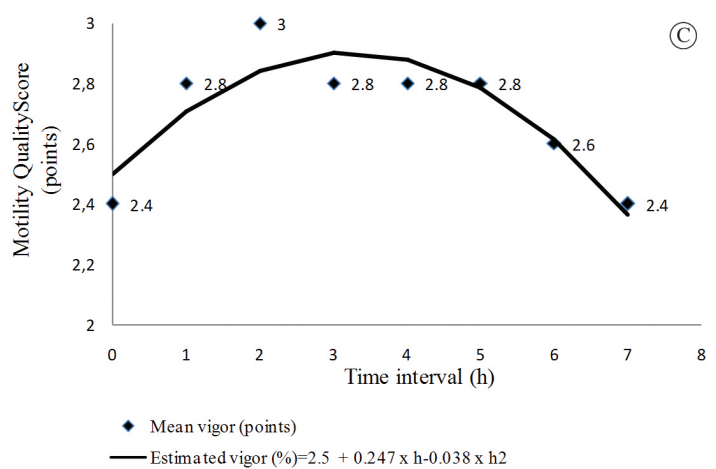

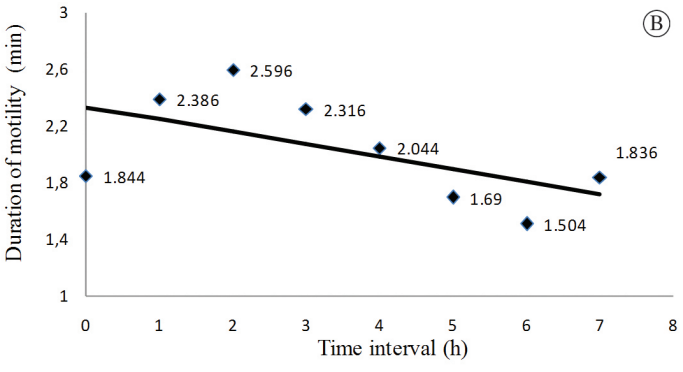

- Duration of motility (min)

—Duration of motility $(\mathrm{min})=2.33-0.88 \mathrm{x}$ cooling hours

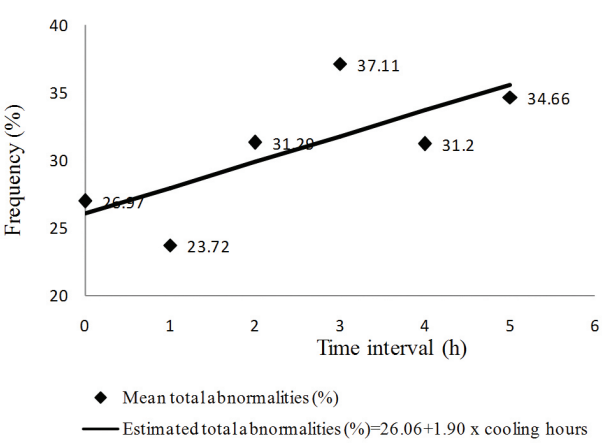

Figure 3. Spermatic parameters of Leiarius marmoratus semen under refrigeration without extenders addition. A Progressive motility (\%), B - Duration of motility ( $\mathrm{min}) \mathrm{C}$ - Motility quality score (points), D - Total abnormalities (\%).
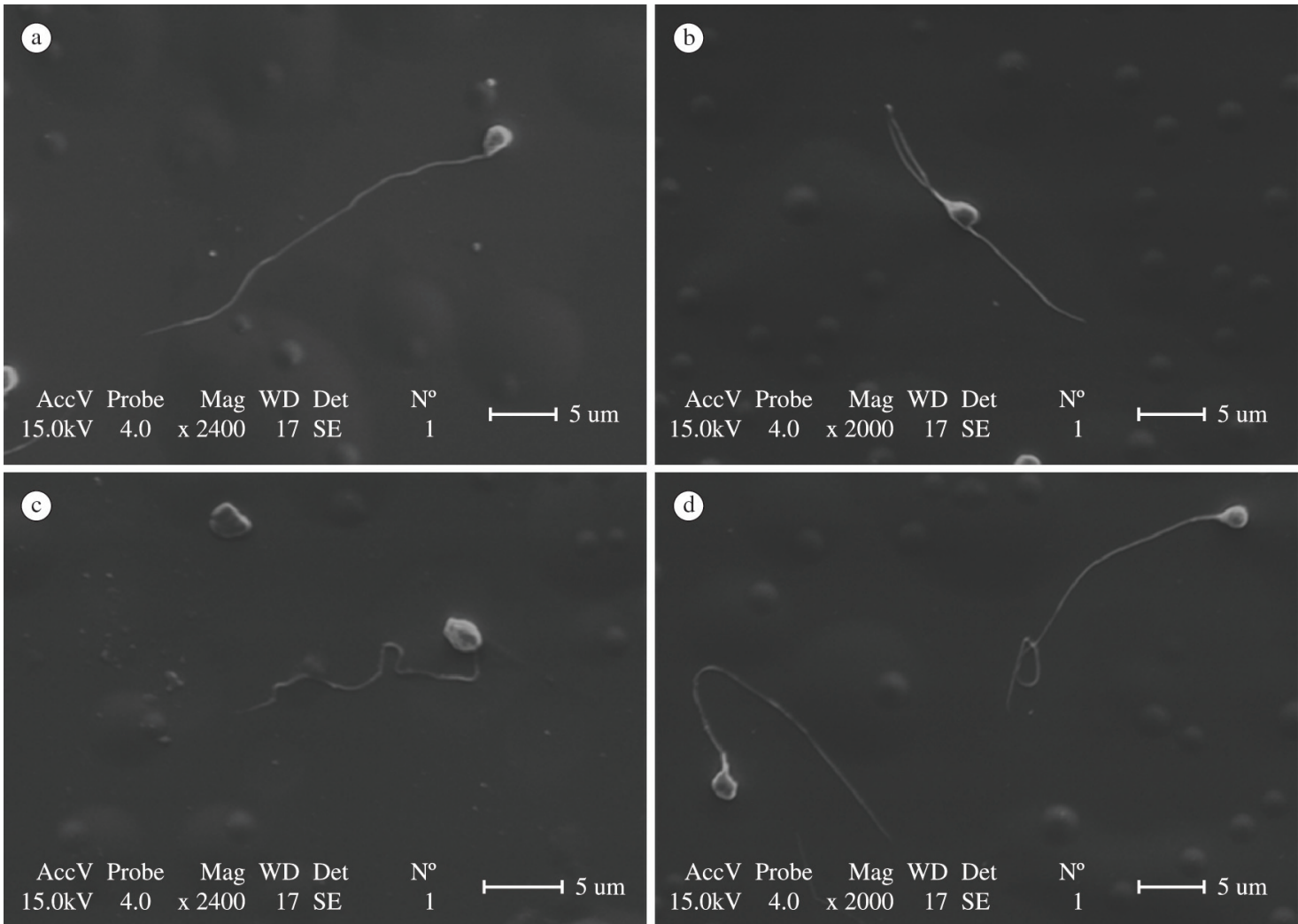

Figure 4. Illustrations of morphologies of spermatozoa of Leiarius marmoratus under light microscopy. (a) normal spermatozoon; (b) bent tail; (c) broken tail (d) coiled tail. 
According to Carneiro et al. (2006), although the semen storage by cooling does not extend the spermatozoa lifetime for similar periods as freezing techniques, it allows a significant increase of motility period when compared to semen exposed to room temperature.

The quadratic pattern of motility quality score rate through storage time was noteworthy. A plausible explanation for this fact relies on the concept of motility quality score itself, defined as the intensity by which majority of the spermatozoa are moving at the moment of observation. Therefore, at the moment of the first evaluation $(T=0)$, majority of spermatozoa exhibited a vigor of about 2.5 points, although the mean motility recorded at this period was equal to $87 \%$. After three hours $(\mathrm{T}=3)$, the mean motility of spermatozoa dropped down to $55 \%$, despite their vigor have reached 3.90 points. This fact might also be related to the acquired capacitation of these spermatozoa after three hours, which was absent at time zero $(T=0)$.

The survival rate recorded in this study, maintaining spermatozoa motility at good values after cooling seems to be inherent to other Siluridae species, such as Clarias gariepinus studied by Mansour et al. (2002) that reported $25 \%$ of motility at $4{ }^{\circ} \mathrm{C}$.

The cooling procedure when carried out improperly causes partial but irreversible damages to spermatozoa. Such damages can be easily characterized by abnormal spermatozoon movement patterns (circular or backward movements). Coincidently, we observed that the progressive motility decreased as the sperm abnormalities increased. It is possible that thermal chock (injuries by cold) might be related to this such a result once cryoprotectant agents were not used (Graham, 1996).

Another reason for increasing abnormality rates was the absence of oxygenation due to drying shrinkage of the semen, as extenders agents were not employed. According to Babiak et al. (2006), one way to avoid spermatozoa degeneration when stored is by diluting them into isotonic solutions, i.e., extender mediums that simulate the seminal fluid features in which the spermatozoa were found. The main benefits of these extender solutions are their ability in maintaining the humidity and avoiding bacterial growth in the medium, allowing the preservation of spermatozoa's fertilizing potential for longer periods.

The cooling technique does not allow semen storage for long periods as those achieved by freezing. Nevertheless, this is a simpler and cheaper technique, once there is no need of cryoprotectants agents and may be performed at any fish breeding facility (Carneiro et al., 2006). These authors, assessing the spermatozoa viability of silver catfish, Rhamdia quelen, reported promising results after 12 days of cold storage without adding cryoprotectants in the medium. No doubt the utilization of cooled semen, kept in a common refrigerator is a practical one. The motility values observed in the sperm of $L$. marmoratus showed that semen remained viable after cooling. These results corroborate those reported by Marques and Godinho (2004), which used cooled semen of Leporinus friderici for seven hours.
When comparing the parameters of the fresh semen to those recorded in the cooled semen (extenders-free) we observed a better spermatic viability to the cooled semen due to maintenance of its qualitative characteristics for a longer period. Even without the presence of extenders the cooled semen remained viable for seven hours. In a practical way, the simple use of a thermal box with ice would allow the transport of genetic material between fish farms nearby as well as avoiding expenses with skilled labor and freezing procedures.

Results from the present study reinforce that cooling storage may bring some advantages for the artificial reproduction in fish, allowing reduction costs with broodstock maintenance as well as minimizing the inconvenience of reproductive asynchrony between males and females during the breeding season. Therefore, the resources related to artificial reproduction procedures in fish farms can be optimized. The flagellar driving force of L. marmoratus spermatozoa remained active for more than seven hours under refrigeration without adding extenders.

\section{Acknowledgments}

The authors thank the owners of Boa Esperança (Pimenta Bueno, Rondônia), Delicious Fish (Sorriso, Mato Grosso) and Buriti (Nova Mutum, Mato Grosso) fish farms for allowing the use of their facilities. We also thank EMBRAPA via Aquabrasil Project for collaborating to this work.

\section{References}

ALAVI, SM. and COSSON, J., 2006. Sperm motility in fishes. (II) Effects of ions and osmolality: a review. Cell Biology International, vol. 30, no. 1, p. 1-14. http://dx.doi.org/10.1016/j. cellbi.2005.06.004. PMid:16278089

BABIAK, I., OTTESEN, O., RUDOLFSEN, G. and JOHNSEN, S., 2006. Quantitative characteristics of Atlantic halibut, Hippoglossus hippoglossus L., semen throughout the reproductive season. Theriogenology, vol. 65, no. 8, p. 1587-1604. http://dx.doi. org/10.1016/j.theriogenology.2005.09.004. PMid:16233911

BENCIC, DC., CLOUD, JG. and INGERMANN, RL., 2000. Carbon dioxide reversibly inhibits sperm motility and fertilizing ability in steelhead (Oncorhynchus mykiss). Fish Physiology and Biochemistry, vol. 23, no. 4, p. 275-281. http://dx.doi. org/10.1023/A:1011157329855.

BILLARD, R., COSSON, J., PERCHEC, J. and LINHART, O., 1995. Biology of sperm and artificial reproduction in carp. Aquaculture (Amsterdam, Netherlands), vol. 129, no. 1-4, p. 95112. http://dx.doi.org/10.1016/0044-8486(94)00231-C.

BILLARD, R. and COSSON, MP., 1986. Sperm motility in rainbow trout, Parasalmo mykiss; effects of $\mathrm{pH}$ and temperature. Reproduction Fish, vol. 44, p. 10-12.

BILLARD, R., LINHART, O., FIERVILLE, F. and COSSON, J., 1997. Motility of European catfish Silurus glanis spermatozoa in testes and milt. Polskie Archiwum Hidrobiology, vol. 44, p. 115-122.

CARNEIRO, PCF., SEGUI, MS., IÓRIS FILHO, CR. and MIKOS, JD., 2006. Viabilidade do sêmen do jundiá, Rhamdia quelen, armazenado sob refrigeração. Revista Acadêmica, vol. 4, p. 11-16. 
CHEREGUINI, O., MARIA CAL, R., DREANNO, C., ORGIER DE BAULNY, B., SUQUET, M. and MAISSE, G., 1997. Shortterm storage and cryopreservation of turbot (Scophthalmus maximus) sperm. Aquatic Living Resources, vol. 10, no. 4, p. 251-255. http:// dx.doi.org/10.1051/alr:1997028.

GALO, JM., STREIT-JUNIOR, DP., SIROL, RN., RIBEIRO, RP., DIGMAYER, M., ANDRADE, VXL. and EBERT, AR., 2011. Spermatic abnormalities of piracanjuba Brycon orbignyanus (Valenciennes, 1849) after cryopreservation. Revista Brasileira de Biologia = Brazilian Journal of Biology, vol. 71, no. 3, p. 693-699. PMid:21881793.

GRAHAM, JK., 1996. Cryopreservation of stallion spermatozoa. The Veterinary Clinics of North America. Equine Practice, vol. 12, no. 1, p. 131-147. PMid:8726455.

HE, S. and WOODS 3rd., LC., 2003. Effects of glycine and alanine on short-term storage and cryopreservation of striped bass (Morone saxatilis) spermatozoa. Cryobiology, vol. 46, no. 1, p. 17-25. http://dx.doi.org/10.1016/S0011-2240(02)00159-1. PMid:12623024

MANSOUR, N., LAHNSTEINER, F. and PATZNER, RA., 2002. The Spermatozoon of the African Catfish: Fine Structure, Motility, Viability and Its Behaviour in Seminal Vesicle Secretion. Journal of Fish Biology, vol. 60, no. 3, p. 545-560. http://dx.doi. org/10.1111/j.1095-8649.2002.tb01683.x.

MARIA, AN., VIVEIROS, ATM., FREITAS, RTF. and OLIVEIRA, AV., 2006. Extenders and cryoprotectants for cooling and freezing of piracanjuba (Brycon orbignyanus) sêmen, an endangered Brazilian teleost fish. Aquaculture (Amsterdam, Netherlands), vol. 260, no. 1-4, p. 298-306. http://dx.doi.org/10.1016/j.aquaculture.2006.06.011.

MARQUES, S. and GODINHO, HP., 2004. Short-term Cold Storage of Sperm from Six Neotropical Characiformes Fishes. Brazilian Archives of Biology and Technology, vol. 47, no. 5, p. 799-804. http://dx.doi.org/10.1590/S1516-89132004000500016.

MATEO, FJ., DELGADO, N. and LOPÉZ, H., 2008. Caracterización Morfométrica del Híbrido Yaque Pintado (Pseudoplatystoma fasciatum x Leiarius marmoratus) y sus Progenitores (Siluriformes: Pimelodidae). Revista Facultad Ciencias Veterinarias, vol. 49, p. $47-60$

OHTA, H. and IZAWA, T., 1996. Diluent for cool storage of the Japanese eel (Anguilla japonica) spermatozoa. Aquaculture (Amsterdam, Netherlands), vol. 142, no. 1-2, p. 107-118. http:// dx.doi.org/10.1016/0044-8486(95)01246-X

RANA, K., 1995. Preservation of gametes. In BROMAGE, NR. and ROBERTS, RJ. (Eds.). Broodstock management and egg and larval quality. Oxford: Blackwell Science. p. 424

SAHINÖZ, E., ARAL, F. and DOĞU, Z., 2007. Changes in Mesopotamian spiny eel, Mastacembelus mastacembelus (Bank \& Solender in Russell, 1794) (Mastacembelidae) milt quality during a spawning period. Theriogenology, vol. 67, no. 4, p. 848-854. http://dx.doi.org/10.1016/j.theriogenology.2006.11.001. PMid:17166575

STOSS, J. and REFSTIE, T., 1983. Short-term storage and cryopreservation of milt from Atlantic salmon and sea trout. Aquaculture (Amsterdam, Netherlands), vol. 30, no. 1-4, p. 229236. http://dx.doi.org/10.1016/0044-8486(83)90165-5.

STREIT-JUNIOR, DP., RIBEIRO, RP., MORAES, GV., VARGAS, LDM., DIGMAYER, M., GALO, JM., POVH, JA. and BRACCINI NETO, J., 2007. Sêmen de pacu (Piaractus mesopotamicus) submetido ao resfriamento ao longo do tempo com diferentes meios diluidores. Revista Biociências, vol. 13, p. 178-187.

VALDEBENITO, I., FLETCHER, C., VERA, V. and FERNÁNDEZ, J., 2009. Factores fisicoquímicos que regulan la motilidad espermática en peces: aspectos básicos y aplicados. Una revisión. Archivos de Medicina Veterinaria, vol. 41, no. 2, p. 97-106. http:// dx.doi.org/10.4067/S0301-732X2009000200002.

WAYMAN, WR., TIERSCH, TR. and THOMAS, RG., 1998. Refrigerated storage and cryopreservation of sperm of red drum, Sciaenops ocellatus L. Aquaculture and Research, vol. 29, no. 4, p. 267-273. http://dx.doi.org/10.1111/j.1365-2109.1998.tb01131.x. 